\title{
Clinical Efficacy of Mannitol (10\%) with Glycerine (10\%) Versus Mannitol (20\%) in Cerebral Oedema
}

\author{
Dr. Avinash Shankar ${ }^{1 *}$, Dr Shubham ${ }^{2}$, Dr Amresh Shankar ${ }^{3}$, Dr. Anuradha Shankar ${ }^{4}$ \\ ${ }^{1} M D$ (internal Medicine),DNB(E\&M); PhD Postgraduate in Endocrinology \& Metabolism (AIIMS-Delhi) \\ Chairman ,National Institute of Health \& Research Institute of Applied Endocrinology Warisaliganj (Nawada) \\ Bihar 805130, India. \\ ${ }^{2}$ MD (Paediatrics) Consultant Paediatrician Delhi, India. \\ ${ }^{3}$ BAMS (BRABU) MHA, Hon Director AarogyamPunarjeevan Ram Bhawan, Ara Garden Road, Jagdeopath \\ ,Baily Road PATNA 14,800014, India. \\ ${ }^{4}$ BAMS (BRABU) Senior Research Fellow Regional Institute of Ayurveda, Itanagar (Arunachal Pradesh), \\ India.
}

*Corresponding Author: Dr. Avinash Shankar, MD(internal Medicine),DNB(E\&M);PhD Postgraduate in Endocrinology \& Metabolism (AIIMS-Delhi) Chairman ,National Institute of Health \& Research Institute of Applied Endocrinology Warisaliganj (Nawada) Bihar 805130, India.

\begin{abstract}
Cerebral oedema is a common cause of unconsciousness and various manifestation in Cerebrovascular accident, head injury, convulsive disorder and encephalitis either due to infection or toxin due to failure of energy dependant Sodium Potassium ATPase pump resulting accumulation of sodium and water, in addition release of free radicals and proteases due to activation of microglial cells disrupts cell membrane and capillaries.
\end{abstract}

Objective of Study: Comparative assessment of clinical efficacy of Mannitol $10 \%$ with Glycerol $10 \%$ versus Mannitol $20 \%$ in cerebral oedema of varied origin

Materials \& Methods: In this study 1171 patients of cerebral oedema of various aetiology attending Medical Emergency of RA Hospital \& Research Centre, Warisaliganj (Nawada) Bihar been selected for comparative evaluation of Mannitol (10\%) with Glycerol (10\%) versus Mannitol (20\%) intravenously to adjudge the clinical efficacy and safety profile.

Result: Patients of Group A taking Mannitol (10\%) with Glycerol (10\%)had grade I clinical response in 99.6\% \% (584/586) without any adversity, residual neurological deficit Or mortality and morbidity while patients of Group B on Mannitol (20\%) only18.4\% (108/585) with15.7\%( 92) mortality and morbidity in $47.6 \%(279)$ cases.

Keywords: Cerebral oedema, Cerebrovascular accident, Sodium potassium ATPase pump, free radicals, Protease, mortality, morbidity.

\section{INTRODUCTION}

Cerebral oedema is a common sequel of cerebro vascular accident (CVA), Head injury, convulsive disorder and infective or toxic involvement of brain. Cerebral oedema pathogenesis at cellular level is complex as - damaged cells swell, injured blood vessels leak and blocked absorption pathways force fluid to enter brain tissues. Cellular and blood vessel damage activate an injury cascade i.e.-release of glutamate into the extracellular space opens Calcium and sodium entry channels on cell membranes. Membrane ATPase pumps releases one calcium ion in exchange for 3 sodium ions which create an osmotic gradient promoting increase water entry to cells and causes dysfunction but not necessarily permanent damage. Ultimately hypoxias deplete the cells' energy stores and disable the sodium - potassium ATPase reducing calcium exchange $(1,2,3)$

Failure of the energy-dependent sodium pump in the cellular membrane causes accumulation of Sodium and water to the intracellular space to maintain osmotic gradient while accumulation of Calcium inside the cell activate intracellular cytotoxic processes. Formation of genes like c-foc and cjun and cytokines and other intermediary substances initiate inflammatory response. Activation of 
Microglia cells releases free radicals and proteases attacks on cell membranes and capillaries which results in the cells recovery impossible $(4,5,6,7)$.

In addition negligent and lack of proper restriction ,investigation and health care counselling and education ,people suffer with dreaded sequel of hypertension i.e.- Cerebrovascular accident results in unconscious, convulsion, paralysis and coma which modify the outcome of the disease and increases the mortality .

To overcome the brain oedema, the commonly prescribed urgent measure remains intravenous mannitol and oxygen inhalation. Usually Oral glycerol remains the choice to relieve brain oedema.

Considering the clinical effect of oral glycerol and availability of Mannitol 10\% with Glycerol 10\%, a clinical study was conducted to evaluate the clinical effect and safety profile of $10 \%$ glycerol with $10 \%$ mannitol versus Mannitol 20\% in management of cerebral oedema of either origin.

\section{Objective of Study}

To adjudge the clinical efficacy of Mannitol 10\% with Glycerol 10\% versus Mannitol 20\% in

\section{Design of Study}

Comparative clinical study

\section{MATERials \& MeTHODS}

\subsection{Material}

Patients of cerebral oedema of either origin attending at RA.Hospital \& Research Centre Emergency were selected for evaluation of Mannitol (10\%) with Glycerol (10\%) versus conventional Mannitol $20 \%$ therapy.

\subsection{Methods}

Parent or attendants of the admitted patients were thoroughly interrogated for the presenting feature onset ,its duration ,treatment taken and their outcome, any history of such attacks in past. All the patients were examined for their blood pressure, temperature, any marks of injury over the head, blood sugar, and sample collected for other vital parameters assessment. Patients were classified in to two groups comprising equal number of patients i.e.-

\begin{tabular}{|c|c|c|}
\hline Clinical status & Group A & Group B \\
\hline Head injury & 54 & 54 \\
\hline Cerebro vascular accident & 315 & 315 \\
\hline Toxemia & 5 & 5 \\
\hline Febrile convulsion & 5 & 5 \\
\hline Convulsive disorder & 181 & 180 \\
\hline Encephlitis & 26 & 26 \\
\hline
\end{tabular}

All the patients irrespective of their cause of unconsciousness Or cerebral oedema were advocated -

- Oxygen inhalation

- Specific treatment (Anti hypertensive measure for hypertension, anti diabetic measure for diabetes mellitus,)

- IV nutrition

- IV chemoprophylaxis

- Other desired measures as per need ( anti convulsant for convulsion )

- Diazepam administration is duly restricted.

While group a patients were given Mannitol 10\% and glycerol 10\% (Glycerol is a potent osmotic dehydrating agent with additional effects on brain metabolism. In doses of $0.25-2.0 \mathrm{~g} / \mathrm{kg}$ glycerol) Intravenous and group B Mannitol 20\%. (Mannitol in a dose of $1.5 \mathrm{~g} / \mathrm{kg}$ body weight was infused over a period of 15 minutes, followed by $0.5 \mathrm{~g} / \mathrm{kg}$ body weight every 8 hours until the patient regained consciousness or for a maximum period of 72 hours.)

Patients were assessed as per following index of assessment i.e.-

\section{INDEX OF ASSESSMENT}

Recovery time from unconsciousness

Status of paralysis 
Neural recovery

- Status of alertness

- Status of speech

- Mental capability

- Motor power and tone

Effect on various bio parameters Post therapy sequel:

- Polyuria

- Polydipsia

- Irritability

- Pulmonary congestion,

- fluid and electrolyte imbalance,

- acidosis,

- electrolyte loss,

- dryness of mouth, thirst,

- marked diuresis,

- urinary retention,

- Oedema,

- headache,

- blurred vision,

- convulsions,

- nausea,

- vomiting,

- hypotension,

- tachycardia,

To assess the safety profile of the administered drug the basic bio parameters i.e. - haematological, hepatic and renal profile are repeated

On the basis of clinical achievement clinical response was graded as

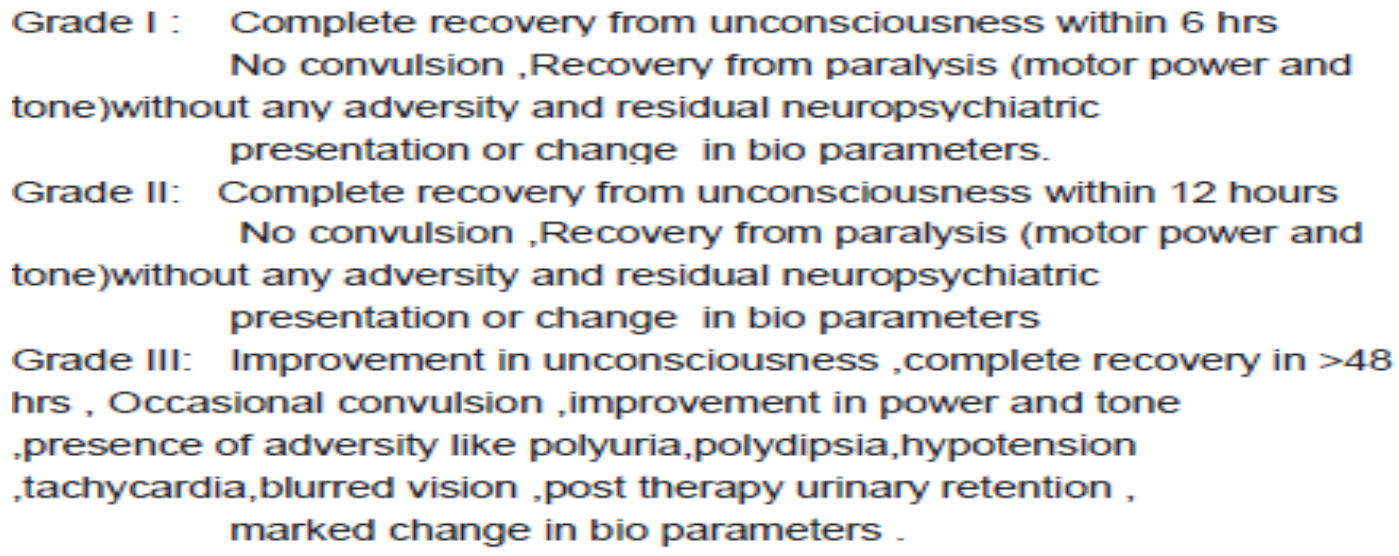

\section{OBSERVATION}

Among the admitted 1171 patients of cerebral oedema 797 (68\%) and 374(32\%) respectively were of male and female respectively. Majority patients ( ) were of age $>50$ years though 14 cases were of age $10-15$ years. 
Table1. Number of patients of cerebral oedema

\begin{tabular}{|c|c|c|c|}
\hline \multirow{2}{*}{ Age group(in yrs) } & \multicolumn{3}{|c|}{ Number of patients } \\
\cline { 2 - 4 } & Male & Female & Total \% \\
\hline $10-15$ & 09 & 05 & 14 \\
\hline $15-20$ & 11 & 13 & 41 \\
\hline $20-25$ & 28 & 34 & 98 \\
\hline $25-30$ & 64 & 26 & 84 \\
\hline $30-35$ & 58 & 29 & 116 \\
\hline $35-40$ & 87 & 24 & 78 \\
\hline $40-45$ & 54 & 30 & 88 \\
\hline $45-50$ & 58 & 54 & 200 \\
\hline $50-55$ & 110 & 70 & 270 \\
\hline $55-60$ & 130 & 82 & $\mathbf{1 1 7 1}$ \\
\hline$>60$ & 188 & $\mathbf{3 7 4}(\mathbf{3 2} \%)$ & \\
\hline
\end{tabular}

pie diagram showing male :female composition

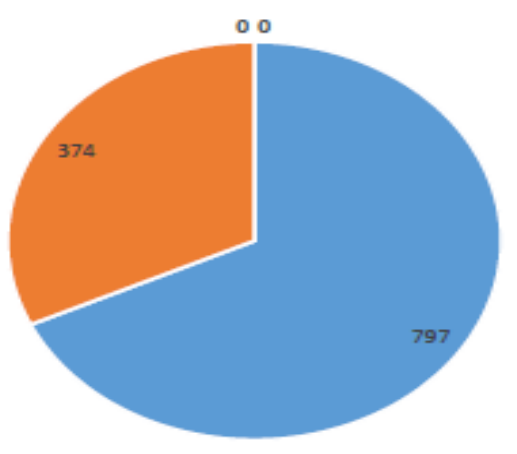

Fig1. Pie diagram showing sex wise composition of patients

Out of all majority $630(53.8 \%)$ were of CVA, 361 (30.8\%) were of convulsive disorder while $108(9.2 \%$ were of head injury

Table2. Shows distribution of patients as per causes of Cerebral Oedema

\begin{tabular}{|c|c|}
\hline Causative factors & Number of patients \\
\hline Head injury & 108 \\
\hline Cerebro vascular accident & 630 \\
\hline Toxemia & 10 \\
\hline Febrile convulsion & 10 \\
\hline Convulsive disorder & 361 \\
\hline Encephlitis & 52 \\
\hline
\end{tabular}

Among the selected patients $77.2 \%$ were hypertensive out of which $9.3 \%$ were with malignant hypertension (average $>160$ )

Table3. Distribution of patients as per average blood pressure record on admission

\begin{tabular}{|c|c|c|c|}
\hline \multirow{2}{*}{$\begin{array}{c}\text { Average blood } \\
\text { pressure (in mmHg) }\end{array}$} & Male & Female & Total \% \\
\hline$<120$ & 152 & 115 & 267 \\
\hline $130-135$ & 74 & 46 & 120 \\
\hline $135-140$ & 74 & 39 & 113 \\
\hline $140-145$ & 91 & 38 & 129 \\
\hline $145-150$ & 95 & 40 & 135 \\
\hline $150-155$ & 101 & 57 & 158 \\
\hline $155-160$ & 100 & 40 & 140 \\
\hline$>160$ & 80 & 29 & 109 \\
\hline Total & $\mathbf{7 6 7}$ & $\mathbf{4 0 4}$ & $\mathbf{1 1 7 1}$ \\
\hline
\end{tabular}

And $75.5 \%$ were diabetic out of which $11.1 \%$ were with random blood sugar $>400 \mathrm{mg} \%$ 
Table4. Distribution of patients as per random blood sugar status

\begin{tabular}{|c|c|c|c|c|}
\hline Random blood & \multicolumn{4}{|c|}{ Number of patients } \\
\cline { 2 - 5 } sugar (in mg \%) & Male & Female & Total & Percent \\
\hline$<200$ & 200 & 87 & 287 & 26.8 \\
\hline $200-250$ & 54 & 40 & 94 & 22.5 \\
\hline $250-300$ & 166 & 84 & 250 & \\
\hline $300-350$ & 89 & 45 & 124 & 11.1 \\
\hline $350-400$ & 223 & 68 & 291 & 125 \\
\hline$>400$ & 75 & 50 & & \\
\hline
\end{tabular}

All admitted cases were unconscious, $36.9 \%$ were presenting with convulsion and $53.8 \%$ with hemiplegic.

Table5. Distribution of patients as per clinical presentation

\begin{tabular}{|c|c|c|c|}
\hline $\begin{array}{c}\text { Clinical } \\
\text { presentation }\end{array}$ & \multicolumn{2}{|c|}{ Number of patients } & Percent \\
\hline Unconscious & 1171 & & $100 \%$ \\
\hline Hemiplegia & 630 & 22.06 & 53.8 \\
\hline Right side & 139 & 77.94 & \\
\hline Left side & 491 & & 36.9 \\
\hline Convulsion & 433 & & \\
\hline
\end{tabular}

$67.3 \%$ patients been admitted within $24 \mathrm{hrs}$ of incident while rest after $24 \mathrm{hrs}$

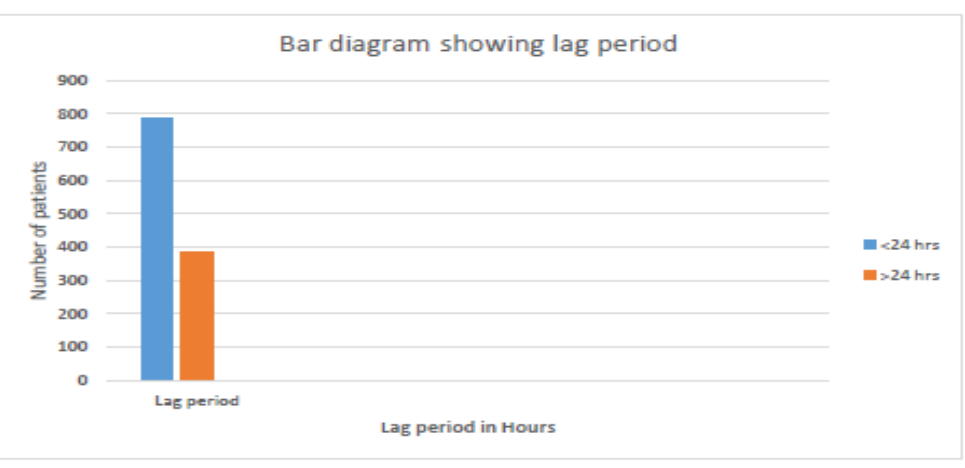

Fig2. Bar diagram showing lag period

Among the patients 704 known hypertensive and 590 known diabetic were not taking any drug while no history has been elucidated in 287 cases.

Table6. Distribution of patients as per previous history of illness

\begin{tabular}{|c|c|}
\hline History of previous illness & Number of patients \\
\hline Hypertensive taking AHT & 296 \\
\hline Hypertensive never taken any drug & 701 \\
\hline Known diabetic taking drugs & 294 \\
\hline Known diabetic not taking any drug & 590 \\
\hline Unknown & 287 \\
\hline
\end{tabular}

Among the selected patients 183 were addict to all types of narcotics while 355 were having no history of any personal habits

Table7. Distribution of patients as per their personal habits

\begin{tabular}{|c|c|}
\hline Personal habits & Number of patients \\
\hline Alcoholic & 302 \\
\hline Smoker & 254 \\
\hline Tabacco chewer & 567 \\
\hline Cannabis smoker & 165 \\
\hline Gutka & 214 \\
\hline All types of narcotics & 183 \\
\hline Non addicts & 355 \\
\hline
\end{tabular}

865 were pure vegetarian while rest were non vegetarian 


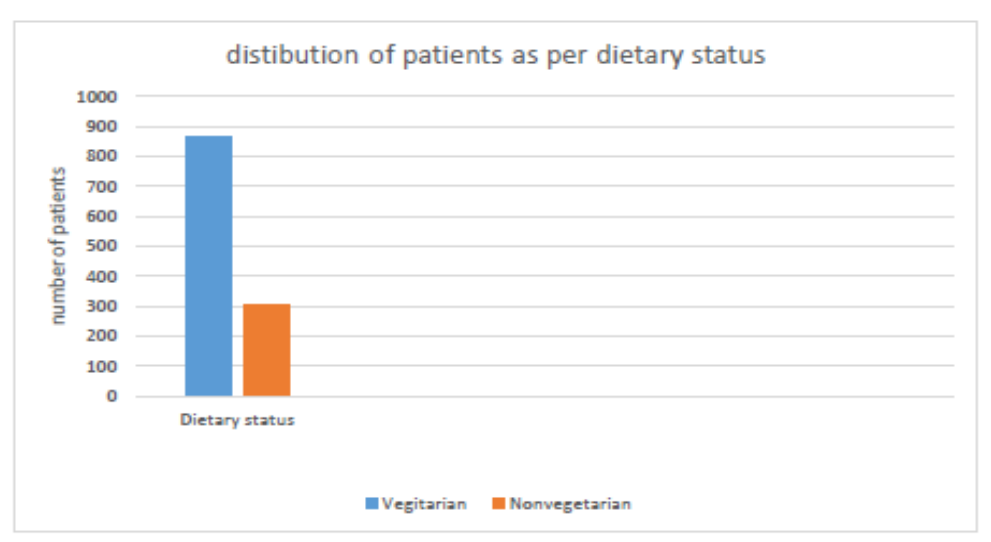

Fig3. Bar diagram showing dietary status

Patients of group A had complete recovery from unconsciousness by 4 hrs while group B patients taken $>12 \mathrm{hrs}$ and 92 patients fails to revive and succumb.

Out of all 536 patients of group A achieved normal CNS function without any residual paralysis, improved general condition and normal life status grade I response in 534 without any adversity or alteration in bio parameters while in group B only 212 patients regained power and tone, improved general condition in 108, normal life status 112, altered CNS function in 132 with residual paralysis in 147 grade I clinical response in only 108 with altered bio parameters in 24 cases

Table8. Out com of the study

\begin{tabular}{|c|c|c|}
\hline Particulars & Number of patients & \\
\hline & Group A & Group B \\
\hline Consciousness recovery time & $4 \mathrm{hrs}$ & $>12 \mathrm{hrs}$ \\
\hline Regain in power and tone & all & 212 \\
\hline \multirow{2}{*}{ Improved general condition } & all & 108 \\
\hline & Quality of life & \\
\hline Normal & 586 & 112 \\
\hline \multirow[t]{2}{*}{ Mortality } & none & 92 \\
\hline & CNS function & \\
\hline Normal & 586 & 214 \\
\hline Altered & none & 132 \\
\hline \multirow[t]{2}{*}{ Residual paralysis } & none & 147 \\
\hline & Safety profile & \\
\hline \multicolumn{3}{|l|}{ Renal profile: } \\
\hline$<26 \mathrm{mg}$ & 586 & 472 \\
\hline \multirow[t]{2}{*}{$>26 \mathrm{mg}$} & - & 21 \\
\hline & Serum Creatinin & \\
\hline$<1.5 \mathrm{mg}$ & 586 & 473 \\
\hline$>1.5 \mathrm{mg}$ & - & 20 \\
\hline \multicolumn{3}{|l|}{ Urine albumin } \\
\hline Positive & none & 24 \\
\hline \multicolumn{3}{|l|}{ Urine RBC } \\
\hline Present & none & 20 \\
\hline \multicolumn{3}{|l|}{ Hepatic profile } \\
\hline \multicolumn{3}{|l|}{ Serum bilirubin } \\
\hline$<1 \mathrm{mg}$ & 586 & 493 \\
\hline \multicolumn{3}{|l|}{ SGOT } \\
\hline$<35 \mathrm{IU}$ & 586 & 493 \\
\hline \multicolumn{3}{|l|}{ SGPT } \\
\hline \multirow[t]{2}{*}{$<35 \mathrm{IU}$} & 586 & 493 \\
\hline & Clinical grade & \\
\hline Grade I & 584 & 108 \\
\hline Grade II & 02 & 106 \\
\hline Grade III & - & 279 \\
\hline
\end{tabular}




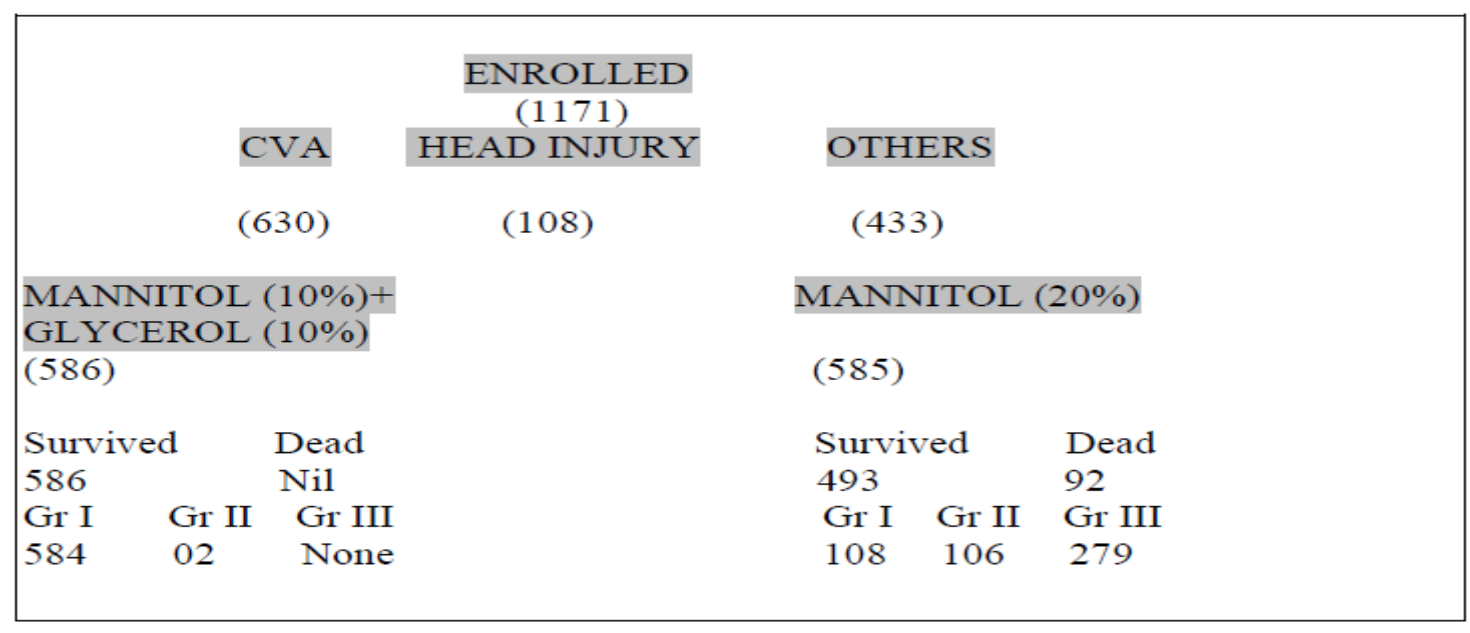

Figure4. Showing schematic presentation of outcome

\section{RESULT}

99.6\%(584/586 )Patients of Cerebral edema on Mannitol 10\% with Glycerol 10\% intravenously had early regain of consciousness and recovery of power, tone, memory and IQ without any adversity or residual neuro deficit than Mannitol 20\% which had grade I clinical response in only $18.4 \%(108 / 585)$ morbidity in $47.6 \%$ ( 279/585 )and mortality in $15.7 \%(92 / 585)$ with altered neurological function

\section{DISCUSSION}

On injury or ischemia of Central nervous system CNS mediators like Glutamate, free fatty acid or high extracellular potassium compounds are released or activated resulting in swelling and damage of nerve cells. In addition substances like histamine, arachidonic acid and free radicals including nitrous oxide are also known mediators causing cerbral oedema. Bradykinin may be involved after cold lesion, concussive brain injury, traumatic spinal cord and ischaemic brain injury. $(8,9)$

In stroke cerebral ischaemia causes loss of membrane ionic pumps and cell swelling while irreversible cell membrane damage is caused by generation of free radicals and proteases.

As per Monro-Kelie hypothesis, change in the volume of any of the three content of skull (inside the skull) i.e. brain $-1400 \mathrm{ml}$, cerebral spinal fluid (CSF) $150 \mathrm{ml}$ and blood $150 \mathrm{ml}$ change the volume of other Conversely, primary blood flow disturbances also lead to brain oedema . $(10,11$, 12)

Significant supremacy of Mannitol 0\% with Glycerol 10\% as compared to Mannitol 20\% can be explained as -

Mannitol is an isomer of sorbitol, administered intravenously confined to the extracellular space, only slightly metabolized and rapidly excreted by the kidney. Approximately $80 \%$ of a $100 \mathrm{~g}$ dose appears in the urine in 3 hours. The drug is freely filtered by the glomeruli with less than $10 \%$ tubular reabsorption; it is not secreted by tubular cells and induces diuresis by elevating the osmolarity of the glomerular filtrate $(13,14,15)$

Mannitol is used to reduce acutely raised intracranial pressure until more definitive treatment can be applied, e.g., after head trauma. $(16,17)$

Such solutions are effective not only in lowering the intracranial pressure, but also in improving the cerebral blood flow and metabolism.

Glycerol is a potent osmotic dehydrating agent with additional effects on brain metabolism. In doses of $0.25-2.0 \mathrm{~g} / \mathrm{kg}$ glycerol decreases intracranial pressure in various disease state however, intravenous doses of $1-2 \mathrm{~g} / \mathrm{kg}$ every $2 \mathrm{hr}$ can be administered safely in severe cases of elevated ICP.

Thus combination of Mannitol and Glycerol decreases the dose of mannitol thus its side effects like diuresis and asthenia in addition Glycerol helps in neural recovery and sustained resolution of cerebral oedema thus ensure prompt recovery of CNS function without alteration in mental capability and IQ Or residual paresis $(18,19,20,21,22)$. 


\section{CONCLUSION}

Mannitol 10\% with Glycerol 10\% proves better than Mannitol 20\% as it spares dose of mannitol and protect from mannitol overdose adversity with better CNS bioregulation without any residual neurodificit.

\section{REFERENCES}

[1] Rosenberg GA. Brain edema and disorders of cerebrospinal fluid circulation. In: Bradley WG, Daroff RB, Ferichel GM, Marsden CD, editors. Neurology in clinical practice. Vol 2.3rd ed. Boston : Butterworth Heinmann 2000;2:1545-59

[2] .Hemphill JC, Beal MF, Gress DR. Critical care in neurology. In : Braunwald E, Fauci AS, Kasper DL, Hauser SL, Longo DL, Jameson JL, editors. Harrison's Principles of Internal Medicine. 15th ed. New York: Mc Graw Hill, 2001:2491-8.

[3] Schilling L, Wahl M. Mediators of cerebral edema. Adv Exp Med Biol 1999; 474:123-41.

[4] Rosenberg GA. Ischemic brain edema. Prog cardiovasc Dis 1999; 42(3):209-16.

[5] Murr R, Berger S, Schurer L, Kempski O, Baethmann SF. Relationship of cerebral blood flow disturbances with brain oedema formation. Acta Neurochir Suppl (Wien) 1993; 59:11- 7.

[6] Biller J, Bruno A. Acute ischaemic stroke. In: Johnson RT, Griffin JW, editors. Current Therapy In Neurologic Disease: 5th ed. St Louis: Mosby, 1997; 191-7.

[7] Cerebrovascular diseases. In: Victor M, Ropper AH, editor. Principles of Neurology. 7th ed. New York: Mc Graw Hill, 2001; 821-924.

[8] Davis M, Lucatorto M. Mannitol revisited. J Neurosci Nurs 1994; 26(3):170-4.

[9] North B, Reilly P. Raised intracranial pressure - a clinical guide 1st ed. Oxford: Heinemann Medical Books, 1990; 71-85.

[10] de los Reyes RA, Ausman JI, Dias FG. Agents for cerebral edema. Clin Neurosurg 1981; 28:98-107.

[11] Richling B. Current status of treatment of cerebral edema. Anaesthesist 1987;36(5):191-6

[12] Berger J, Levy RM. Infection of the nervous system. In:Grotta JC, editor. Management of acutely ill neurological patient. New York: Churchill Livingstone. 1993; 135-53.

[13] Bennett JE. Cryptococcosis. In: Braunwald E, Fauci AS, Kasper DL, Hauser SL, Longo DL, Jameson JL, editors. Harrison's Principles of Internal Medicine. 15th ed. New York: Mc Graw Hill, 2001; 1174-5. 24

[14] Meyer, J. S., Fukuuchi, Y., Shimazu, K., et al.: Effect of intravenous infusion of glycerol on hemispheric blood flow and metabolism in patients with acute cerebral infarction. Stroke 3: 168-185, 1972

[15] Meyer, J. S., Ito, Y., Okamoto, N., et al.: Circulatory and metabolic effects of glycerol infusion in patients with recent cerebral infarction. Circulation 51: 701 -712, 1975

[16] Cantore, G., Guidetti, B. and Virno, M.: Oral glycerol for the reduction of in tracranial pressure. J. Neurosurg. 21: 278-283, 1964

[17] Buckell, M. and Walsh, L.: Effect of glycerol by mouth on raised intracranial pressure in man. Lancet 2: 1151-1152. 1964

[18] Meyer, J. S., Charney, J. Z., Rivera, V. M., et al.: Treatment with glycerol of cerebral edema due to acute cerebral infarction. Lancet 2: 993-997, 1971

[19] Newkirk, T. A., Tourtellotte, W. W. and Reinglass, J. L.: Prolonged control of increased intracranial pressure with glycerin. Arch. Neurol. 27: 95-96, 1972

[20] Mathew, N. T., Meyer, J. S., Rivera, V. M., et al.: Double-blind evaluation of glycerol therapy in acute cerebral infarction. Lancet 2: 1327-1329, 1972

[21] Reinglass, J. L.: Dose response curve of intravenous glycerol in the treatment of cerebral edema due to trauma. Neurology (Minneap.) 24: 743-747, 1974.

[22] Frithz, G. and Werner, I.: Effect of glycerol infusion in acute cerebral infarction. Acta. Med. Scand. 198: 287-289. 1975.

Citation: Dr. Avinash Shankar, et.al. (2019). "Clinical Efficacy of Mannitol (10\%) with Glycerine (10\%) Versus Mannitol (20\%) in Cerebral Oedema". International Journal of Clinical Chemistry and Laboratory Medicine (IJCCLM), 5(2), pp.1-8, DOI: http://dx.doi.org/10.20431/2455-7153.0502001.

Copyright: () 2019 Authors. This is an open-access article distributed under the terms of the Creative Commons Attribution License, which permits unrestricted use, distribution, and reproduction in any medium, provided the original author and source are credited. 